\title{
Perancangan Sistem Informasi Persediaan Alat Tulis Kantor Berbasis Web
}

\author{
Ita Erliyani ${ }^{1}$, Winda Afriandini ${ }^{2}$, Titys Wicaksono Wibowo ${ }^{3}$ \\ ${ }^{1,2}$ Program Studi Sistem Informasi Universitas Raharja, ${ }^{3}$ Program Studi Sistem Komputer \\ Universitas Raharja \\ Email : *1 itaerliyani@ raharja.info, ${ }^{2}$ winda.apriandini@ raharja.info, \\ titya.wicaksono@rahraja.info
}

\begin{abstract}
Abstrak
Revolusi 4.0 yang terjadi bergerak, tidak hanya mengenai Revolusi di bidang industri namun juga di bidang informasi. Pengambilan keputusan untuk mengelola sistem Alat Tulis Kantor. Khususnya sistem persediaan alat tulis kantor memegang peranan sangat penting bagi proses persediaan alat tulis kantor pada RSUP.dr.Sitanala dalam bidang inventory, menyediakan informasi laporan stok barang yang masih manual untuk permintaan barang alat tulis kantor. Tujuan penelitian ini adalah merancang sistem yang dapat memberikan informasi yang update dan memudahkan user untuk mengajukan permintaan barang. Dalam penelitian ini, penulis menggunakan metode analisis PIECES, metode analisis untuk program Unified Modeling Language (UML), dirancang menggunakan bahasa pemrograman PHP (Hypertext Preprocessor), dan dengan database MySql. Hal ini menjadi dasar pemikiran bagaimana penulis menganalisa sistem persediaan barang yang ada pada RSUP.dr.Sitanala sehingga dapat memudahkan dalam menginput permintaan barang tersebut untuk mendapatkan laporan laporan yang efektif dan efisien.
\end{abstract}

Kata kunci: ATK, Sistem Informasi, dan Web

\begin{abstract}
The 4.0 revolution that is taking place also moves, not only about the Revolution in the industrial field but also in the information field. Decision making to regulate the Office Stationery system. Especially the office stationery inventory system plays an important role in the process of procuring office stationery in the RSUP. Dr.Salala in the field of inventory, provides information about inventory reports that are still manual for requests for office stationery. The purpose of this study is to design a system that can provide updated information and make it easier for users to submit requests for goods. In this study, the authors used the PIECES analysis method, the analysis method for the Unified Modeling Language (UML) program, designed using the PHP (Hypertext Preprocessor) programming language, and with the MySql database. This is the rationale for how the authors analyze the procurement system in RSUP. Dr. Salala can facilitate the inventory of goods requested for effective and efficient reporting.
\end{abstract}

Keywords: ATK, Information Systems, and the Web.

\section{Pendahuluan}

Rumah sakit adalah salah satu dari sekian banyak bidang kesehatan yang tidak luput dari kemajuan teknilogi. Untuk itu banyak kebutuhan-kebutungan sistem yang diharapkan dapat mampu mengatasi dan memperingan kinerja dari para pegawai rumah sakit, sehingga dapat melakukan pelayanan dengan baik. Rumah sakit kusta sintanala ( RSK Sintanala ) salah 
satunya, rumah sakit yang merupakan pindahan dari leprosarium lenteng agung yang didikirina pada 28 juli 1951. Pada tahun 1962 berubah nama menjadi Pusat Rehabilitasi sintanala. Dalam upaya peningkatan sistem persedian alat tulis kantor untuk mempermudah pelacakan, pendataan dan laporan alat tulis kantor pada rumah tangga dan perlengkapan RSUP dr. Sintanala, yang selama ini proses pendataan masih dilakukan secara manual sehingga banyak kesulitan yang didapatkan saat proses audit dan pelaporan.

\section{Metode Penelitian}

Pada penelitian yang dilakukan di RSUP dr.Sintanala dalam pengumpulan data yang dilakukan dalam perancangan sistem informasi persediaan alat tulis kantor berbasis web pada subbag RSUP. Dr. Sintanala, menggunakan beberapa metode :

1. Observasi (Observasi Research)

Adalah suatu metode yang digunakan penulis untuk mengumpulkan data dan mendapatkan hal-hal yang diperlukan untuk proses penulisan dengan cara mendatangi pada RSUP.dr.Sitanala, jalan Dr.Sitanala No.2 Neglasari Tangerang, Banten. Mengenai sistem yang sudah ada pada rumah sakit tersebut.

2. Wawancara (interview Research)

Adalah suatu metode dimana penulis mendapatkan data dan keterangan mengenai data suatu hal dengan cara wawancara secara langsung dengan stakeholder Ibu Masarya Simanjuntak, S.E.,M.Si selaku kepala sub bagian rumah tangga dan perlengkapan, mengenai sistem yang digunakan pada rumah sakit tersebut atau tanya jawab dengan pihak-pihak yang terkait.

3. Studi kepustakaan (Library Research)

Penelitian yang dilakukan untuk mendapatkan informasi yang terkait dengan permasalahan yang akan diteliti, penulis mendapatkan data dengan cara mempelajari literatur yang ada di buku dan bahan - bahan yang berkaitan dengan materi dalam pembahasan persediaan barang administrasi pada subbag RSUP. dr. sitanala.

\section{Analisa PIECES}

Penggunaan analisa PIECES ini agar dapat melihat seberapa besar manfaat yang didadapatkan pada sistem usulan yang akan dirancang dan digunakan pada RSUP. Dr.Sintanala. Dalam penggunaan analisa PIECES peneliti dapat memperoleh pokok-pokok permasalahan yang lebih spesifik mengenai kinerja, informasi, ekonomi, pengendalian, efisiensi serta pelayanan yang dimiliki RSUP.dr.Sitanala.

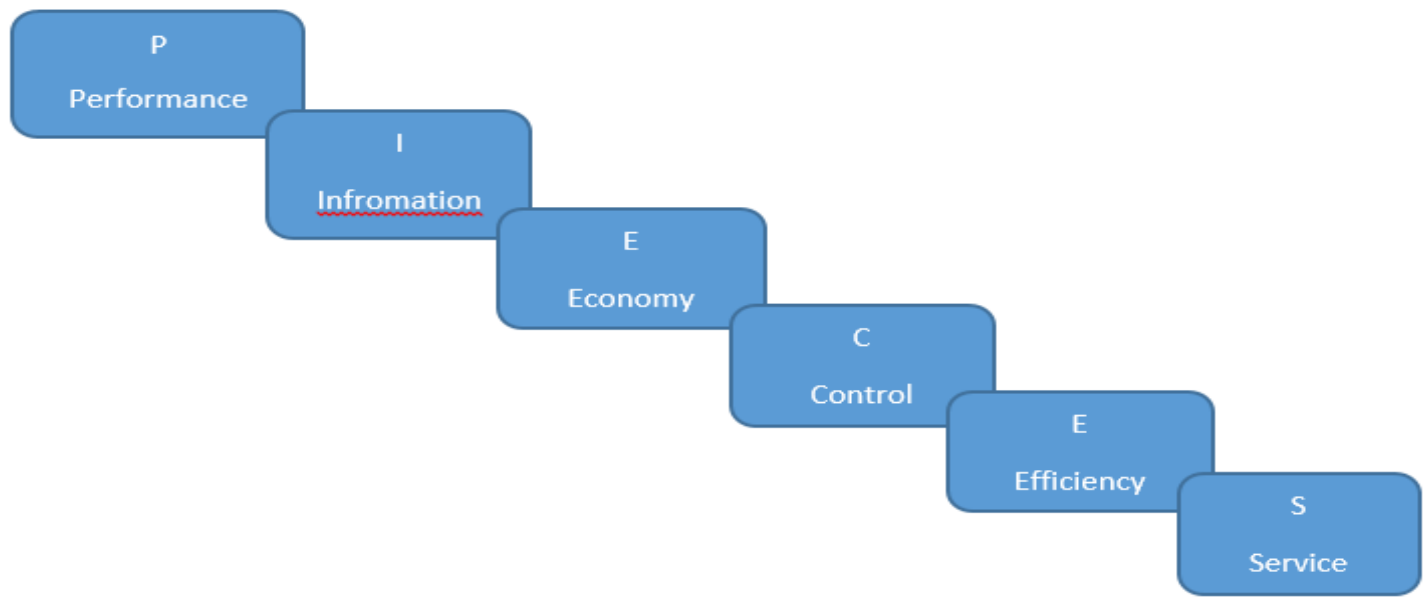

Gambar1. Analisa PIECES. 


\section{TINJAUAN PUSTAKA}

\section{Definisi Rumah sakit}

Menurut peraturan menteri Kesehatan Republik Indonesia No. 340/MENKES/PER/III/2010. Rumah sakit adalah institusi pelayanan kesehatan yang menyelenggarakan pelayanan kesehatan perorangan secara paripurna yang menyediakan pelayanan rawat inap, rawat jalan dan gawat darurat. [1]

\section{Definisi Alat Tulis Kantor (ATK)}

Alat Tulis Kantor (ATK) mendefinisikan manajemen arsip sebagai proses pengawasan, penyimpanan, dan pengamanan dokumen serta arsip, baik dalam bentuk kertas maupun media elektronik.[2]

\section{Definisi Persediaan}

Persediaan adalah menentukan keseimbangan antara investasi persediaan dan pelayanan pelanggan. Tujuan persediaan tidak akan pernah mencapai strategi berbiaya rendah tanpa manajemen persediaan yang baik.[3]

\section{Definisi Perancangan Sistem}

Perancangan Sistem adalah setiap rancangan harus memenuhi kebutuhan penggunanya dan dapat berfungsi dengan baik, fungsi timbul akibat dari adanya kebutuhan manusia dalam usaha untuk mempertahankan serta mengembangkan hidup dan kehidupannya di alam semesta ini.[4]

\section{Definisi Analisa Sistem}

Analisis sistem adalah proses penguraian sistem informasi ke bagian komponennya, dengan tujuan untuk mengidentifikasi serta mengevaluasi permasalahan, kesempatan, hambatan juga perbaikannya.[5]

\section{Definisi Database}

Database baik dalam bentuk database terstruktur dan tidak terstruktur dibutuhkan sebagai tempat penyimpanan tetap untuk merekam kegiatan proses transaksi bisnis. Database terstruktur merupakan organisasi kumpulan data yang menggunakan sistem manajemen database yang didukung konsep DML (Data Manipulation Language) dan DDL (Data Definition Language). Dimana DML merupakan proses manipulasi yang menggunakan perintah sql seperti select, insert, update, delete, dan lain-lain sedangkan DDL merupakan proses pendefinisian database yang menggunakan perintah sql seperti create, table, drop table, dan lain-lain.[6]

\section{LITERATUR REVIEW}

Literature review adalah mempelajari teori-teori dan mencari informasi yang berhubungan dengan permasalahan sesuai dengan judul penelitian ini.[7]

Berikut adalah referensi-referensi yang didapat dari penelitian-penelitian sebelumnya yang dijadiakan acuan dalam pengumpulan informasi :

1. Penelitian dalam sebuah Jurnal Technomedia Journal yang dilakukan oleh Saryani, Havizar, dan Angga (2019)[8], yang dimana dalam penelitiannya menemukan sebuah masalah yaitu Dimana sistem yang berjalan masih masih menggunakan sistem pembukuan tulis secara manual. Dan dikerjakan dengan cara memasukan satu persatu nomor per kepala dari setiap jenis barang ATK (Alat Tulis Kantor) yang masuk pada kelurahan Karangsari. Pengolahan datanya yang masih manual menggunakan microsoft Excel sering mengakibatkan kesalahan dalam penginputan data, begitu juga di dalam pencarian barang yang menggunakan kode barang. Dengan kesalahan yang terjadi pada melakukan pencatatan pemasukan dan pengeluaran barang mengakibatkan data jumlah barang tidak 
sesuai dengan data jumlah fisik. Dan masih didapati data yang sudah ada sehingga terjadi pengulangan/redundancy data dalam penginputan barang ATK (Alat Tulis Kantor) di Kelurahan Karangsari. Dengan kurang maksimalnya data yang dimasukan maka akan memperlambat terhadap pelayanan perihal dokumen identitas kependudukan untuk masyarakat. Metode yang dilakukan adalah dengan melakukan observasi pada Kelurahan Karangsari selaku unit jasa pelayanan terhadap masyarakat dan menganalisa prosedur dan sistem yang telah berjalan yang berkaitan dengan barang ATK (Alat Tulis Kantor) serta menggambarkan dalam bentuk Unified Modelling Language (UML). Penelitian ini diharapkan dapat menghasilkan suatu hasilan sistem informasi berbasis online untuk mengelola data dengan baik yang dapat memperoleh informasi secara akurat, cepat, tepat dan informatif untuk keperluan di kemudian hari.

2. Penelitian yang dilakukan oleh Ani Oktarini Sari, dan Elan Nuari (September 2017)[9], yang berjudul "Rancang Bangun Sistem Informasi Persedian Barang Berbasis Web Dengan Metode Fast" pada Jurnal PILAR Nusa Mandiri. Penelitian ini berisi : dengan metode observasi permasalahan yang dihadapi masih mengalami kendala yaitu pencatatan yang masih manual dari transaksi permintaan barang sampai tidak tepat waktu dalam pelaporan stok barang. Sistem yang berjalan sebelumnya yaitu masih manual seperti permintaan barang ke gudang masih menggunakan surat permintaan hal ini mengakibatkan ketidak cocokan antara stok barang dengan stok fisik yang ada. Dalam jurnal ini, rancang bangun sistem informasi persediaan barang berbasis website menggunakan metode pengembangan sistem yaitu FAST (Framework for the Application System Thinking) terdiri dari fase-fase Scope Definition, Problem Analysis, Requirements Analysis, Logical Design dan Physical Design. Perancangan Sistem Informasinya menggunakan bahasa pemrograman PHP dan HTML serta MYSQL sebagai databasenya. Peneliti menggambarkan solusi dengan membuat sistem yang terkomputerisasi yang berbasis website dari mulai pengolahan data untuk keluar masuk barang, pencarian data yang terorganisir dengan baik sesuai dengan level akses admin, sales dan gudang, sehingga data persediaan barang/stok barang dapat terpantau dengan baik serta file data barang masuk dan keluar tersimpan dengan baik dan dapat diakses dengan mudah ketika dibutuhkan.

3. Penelitian Penelitian yang telah dilakukan oleh Sri Rahayu dan Tuti Nurhaeni (2016)[10], Yang berjudul "Sistem Persediaan Alat Tulis Kantor Sebagai Penunjang Pengambilan Keputusan Bagian Logistik Di Perguruan Tinggi Raharja". Penelitian ini membahas tentang penelitian terhadap sistem persediaan alat tulis kantor di Perguruan Tinggi Raharja karena masih menggunakan sistem semi komputerisasi. Metodologi yang digunakan adalah metode wawancara dan observasi. Implementasi berupa hasil akhir yang dicapai yaitu terbentuknya suatu sistem informasi berbasis Web yang dikoneksikan dengan database server yang memudahkan pengelolaan data dan menghasilkan informasi sebagai penunjang keputusan user.

\section{PERMASALAHAN}

Setelah melakukan analisa berjalan pada RSUP.dr.Sintanala, ditemukan beberapa masalah yang dihadapi saat melakukan kegiatan administrasi alat tulis kantor (ATK) diantaranya :

1. Sistem pencatatan pengandaan alat tulis kantor (ATK) pada RSUD dr. Sintanala masih menggunakan kertas yang dilakukan secara manual. Sehingga sering terjadi kehilangan Nota permintaan barang alat tulis kantor (ATK).

2. Kontrol dalam pengelolaan data yang kurang baik Karena adanya redudansi data yang mengkaibatkan kesamaan data sehingga saat akan membuat laporan para karyawan harus melakukan pengitungan atau pengecekan ulang dengan teliti sehingga laporan yang akan disampaikan sesuai dengan data dilapangan. 
3. Hasil Dan Pembahasan

Analisa Sistem Yang Berjalan

Analisa usecase diagram pada sistem berjalan RSUD dr.Sintanala

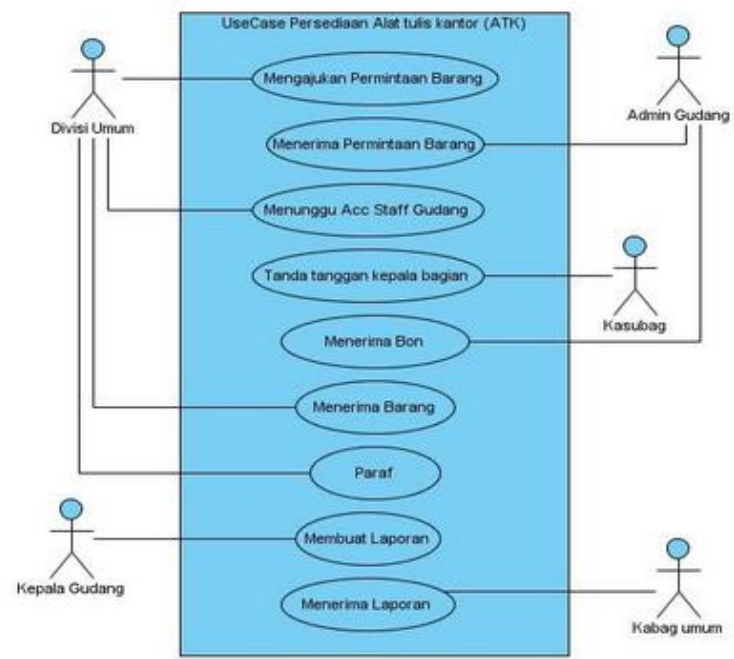

Gambar 2. Usecase Diagram Persedian Alat Tulis Kantor (ATK)

Keterangan

1. Terdiri dari satu sistem persediaan alat tulis kantor (ATK)

2. Terdiri dari 5 actor yang berinteraksi dengan sistem : Divisi umum, admin gudang, kasubag, kepala gudang dan kabag umum.

3. Terdiri dari 9 usecase yang dilakukan oleh actor dalam sistem persedian alat tulis kantor (ATK) diantaranya : Mengajukan permintaan barang,menerima permintaan barang, menunggu acc staff gudang, tanda tangan kepala bagian, menerima bon, menerima barang, paraf , membuat laporan dan menerima laporan.

\section{Analisa PIECES}

Penelitian ini menggunakan metode analisa PIECES untuk mengevaluasi Performance (Kinerja), Information (Informasi), Economi (Ekonomi), Control (Pengendalian), Efficiency (Efisiensi), Service (Pelayanan). Metode analisa PIECES digunakan untuk mengetahui manfaat dari sistem usulan yang dilakukan. Berikut adalah hasil analisa PIECES yang telah dilakukan :

Tabel 1. Analisa PIECES

\begin{tabular}{|l|l|l|}
\hline \multicolumn{1}{|c|}{ Analisa } & \multicolumn{1}{|c|}{ Sistem Lama } & \multicolumn{1}{|c|}{ Sistem Yang Akan Diinginkan } \\
\hline Performance & Beban kerja lebih rumit & $\begin{array}{l}\text { Beban kerja lebih ringan sehingga } \\
\text { meningkatkan kinerja }\end{array}$ \\
\hline Informasi & $\begin{array}{l}\text { Data laporan bon permintaan } \\
\text { barang mudah hilang. }\end{array}$ & $\begin{array}{l}\text { Data laporan bon permintaan barang } \\
\text { ATK (Alat tulis kantor) akan } \\
\text { tersimpan dalam jangka waktu lebih } \\
\text { lama dan tidak akan hilang. }\end{array}$ \\
\hline Economi & $\begin{array}{l}\text { Penggunaan kertas yang masih } \\
\text { manual sangat boros karena jika } \\
\text { terjadi kehilangan bon budah } \\
\text { permintaan barang mudah }\end{array}$ & $\begin{array}{l}\text { Dengan sistem yang sumemat } \\
\text { terkomputerisasi akan mengheman } \\
\text { waktu dan penggunaan kertas. }\end{array}$ \\
\hline
\end{tabular}




\begin{tabular}{|l|l|l|}
\hline & hilang. & \\
\hline Control & $\begin{array}{l}\text { Control dalam pengolahan data } \\
\text { kurang teliti sehingga sering } \\
\text { terjadi kesamaan data }\end{array}$ & $\begin{array}{l}\text { Data akan lebih aman karena tidak } \\
\text { akan ada kesamaan data dalam file }\end{array}$ \\
\hline Efficiency & $\begin{array}{l}\text { Banyak waktu yang terbuang } \\
\text { karena harus mengecek dan } \\
\text { menginput. }\end{array}$ & $\begin{array}{l}\text { Waktu lebih singkat karena setelah } \\
\text { melakukan penginputan maka data } \\
\text { tersebut akan tersimpan dengan } \\
\text { otomatis }\end{array}$ \\
\hline Service & $\begin{array}{l}\text { Sistem yang berjalan } \\
\text { menggunakan ms. Excel tetapi } \\
\text { staff gudang mencetak ulang data } \\
\text { untuk dilaporkan berbentuk } \\
\text { kertas. }\end{array}$ & $\begin{array}{l}\text { Sistem komputerisasi menginput data } \\
\text { ATK (Alat tulis kantor) lalu tersimpan } \\
\text { di menu laporan. }\end{array}$ \\
\hline
\end{tabular}

\section{Alternatif Pemecahan Masalah}

Melihat permasalahan yang sering terjadi, maka untuk mengatasi hal tersebut dibutuhkan alternatif pemecahan masalah sebagai berikut:

1. Membuatkan sistem yang terkomputerisasi untuk sistem persediaan barang, untuk mendapatkan informasi mengenai stock barang secara update sehingga stock barang bisa terkontrol.

2. Membuat sistem persediaan barang yang mampu melakukan pengecekan dan dapat mengontrol ulang secara keseluruhan barang yang dibutuhkan dan jumlahnya yang tinggal sedikit.

\section{Rancangan sistem Usulan}

\section{Tampilan Halaman Login}

Berikut merupakan tampilan halaman login bagi user, admin, dan Kepala Subbag. User, admin, dan Kepala Subbag login dengan memasukkan NIP dan password sebanyak 8 digit

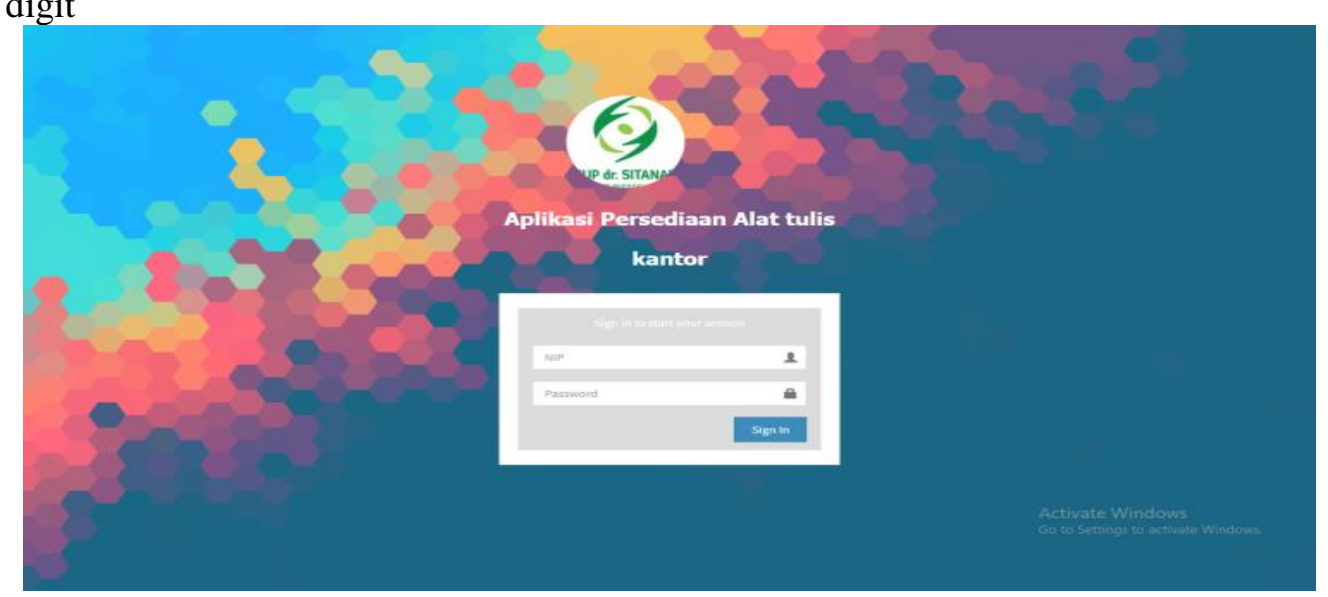

Gambar 3. Rancangan Tampilan Login.

\section{Tampilan Halaman Menu Data Master}

halaman data master admin dimana didalamnya terdapat menu pengguna, menu barang, тепи kategori, dan тепи divisi yang digunakan untuk menginput data master. 
DATA MASTER ADMIN ↔

Pengendallan Persediaan Barang Habis Pakit

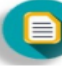

Pengguna

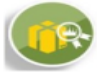

Barang

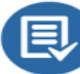

Kategori

Gambar 4. Rancangan Tampilan Menu Data Master.

\section{Tampilan Halaman Menu Transaksi}

Berikut merupakan halaman menu transaksi admin, user, dan Kepala Subbag dimana masing-masing memiliki tampilan menu transaksi yang berbeda sesuai dengan hak aksesnya.

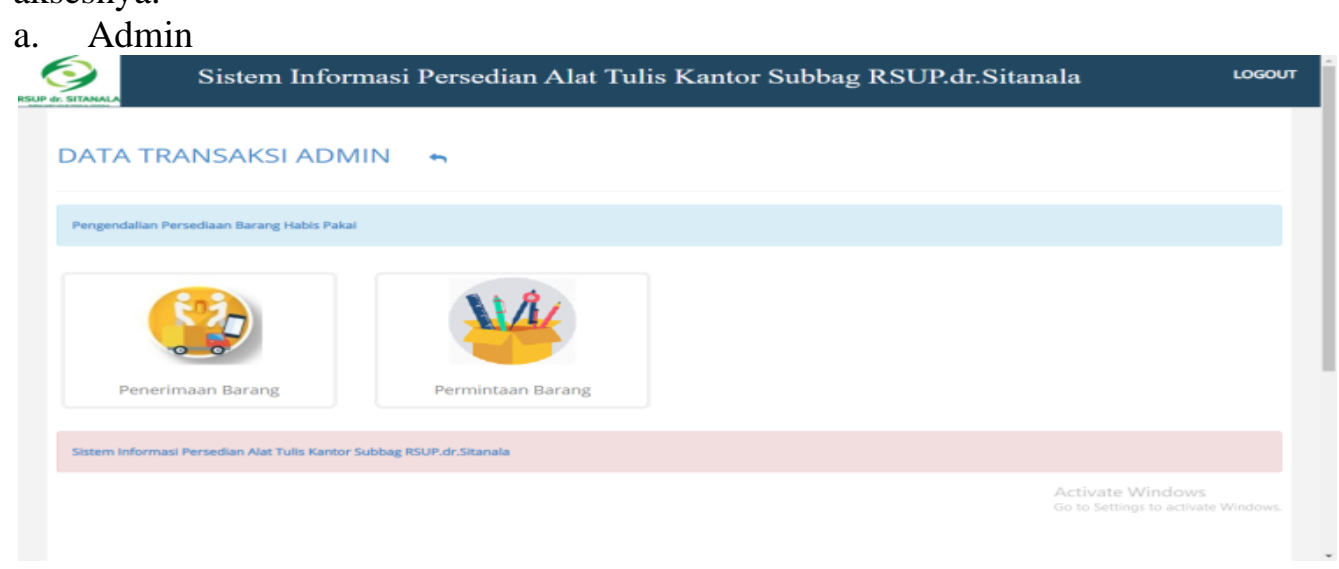

Gambar 5. Rancangan Tampilan Transaksi Admin.

b. User

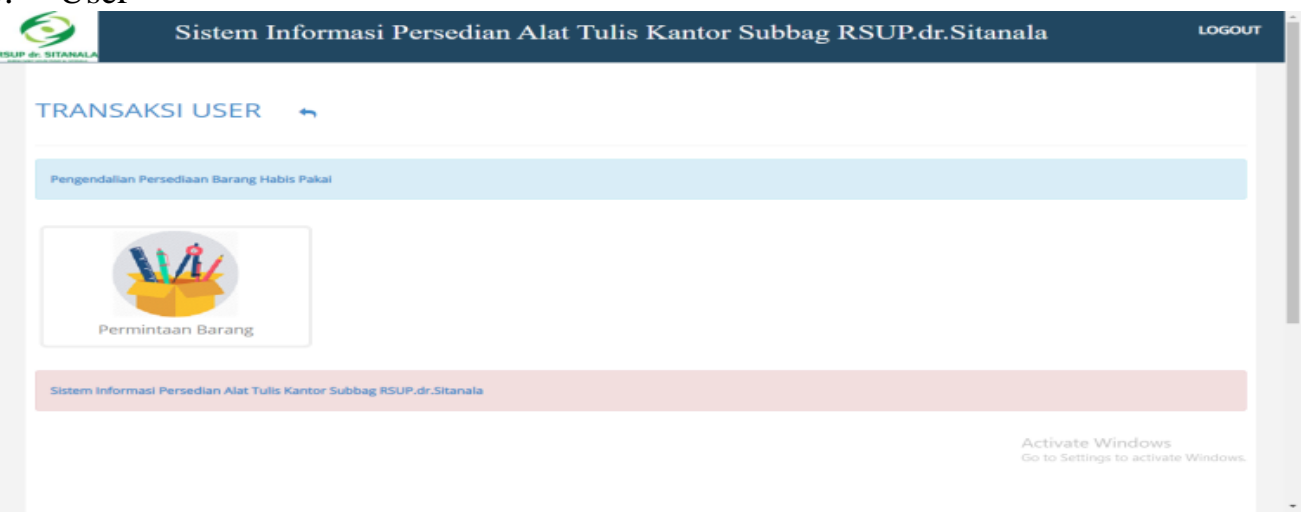

Gambar 6. Rancangan Tampilan Transaksi User.

\section{Tampilan Halaman Menu Penerimaan Barang}

Berikut merupakan halaman menu penerimaan barang pada dashboard admin yang digunakan untuk menginput data transaksi penerimaan barang. 


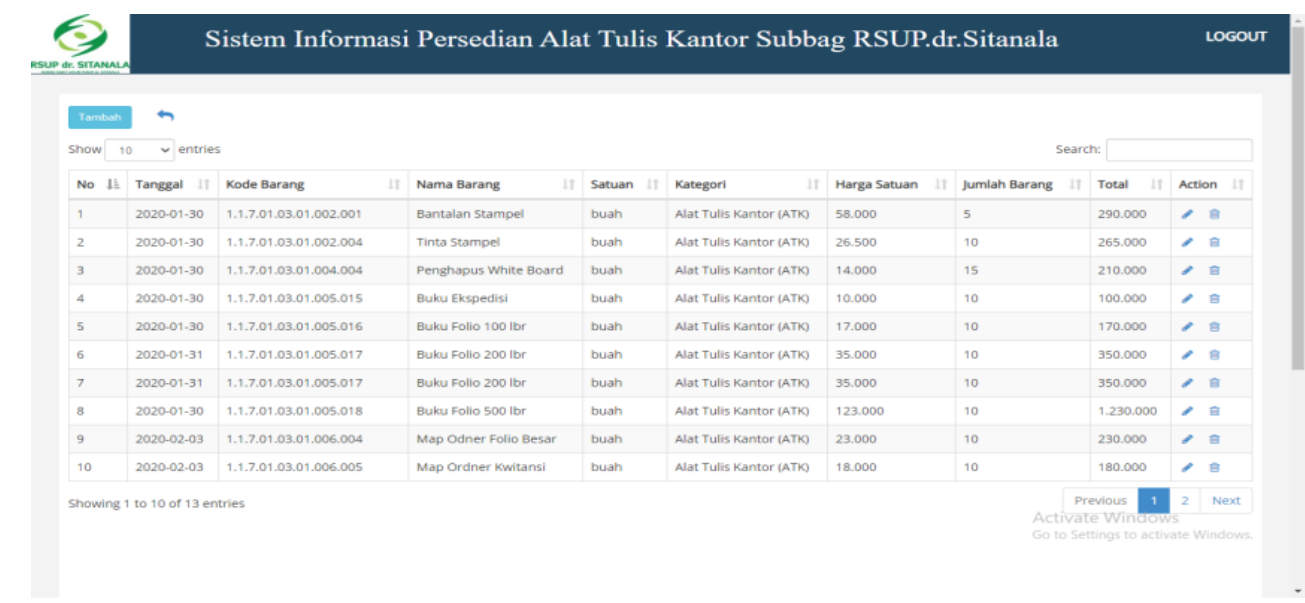

Gambar 7. Rancangan Tampilan Penerimanan Barang.

\section{Tampilan Halaman Menu Laporan}

Berikut merupakan tampilan halaman menu laporan pada dashboard admin dan kepala Subbag dimana didalamnya terdapat empat macam menu laporan yaitu laporan persediaan barang, laporan penerimaan barang, laporan permintaan barang, dan laporan grafik.

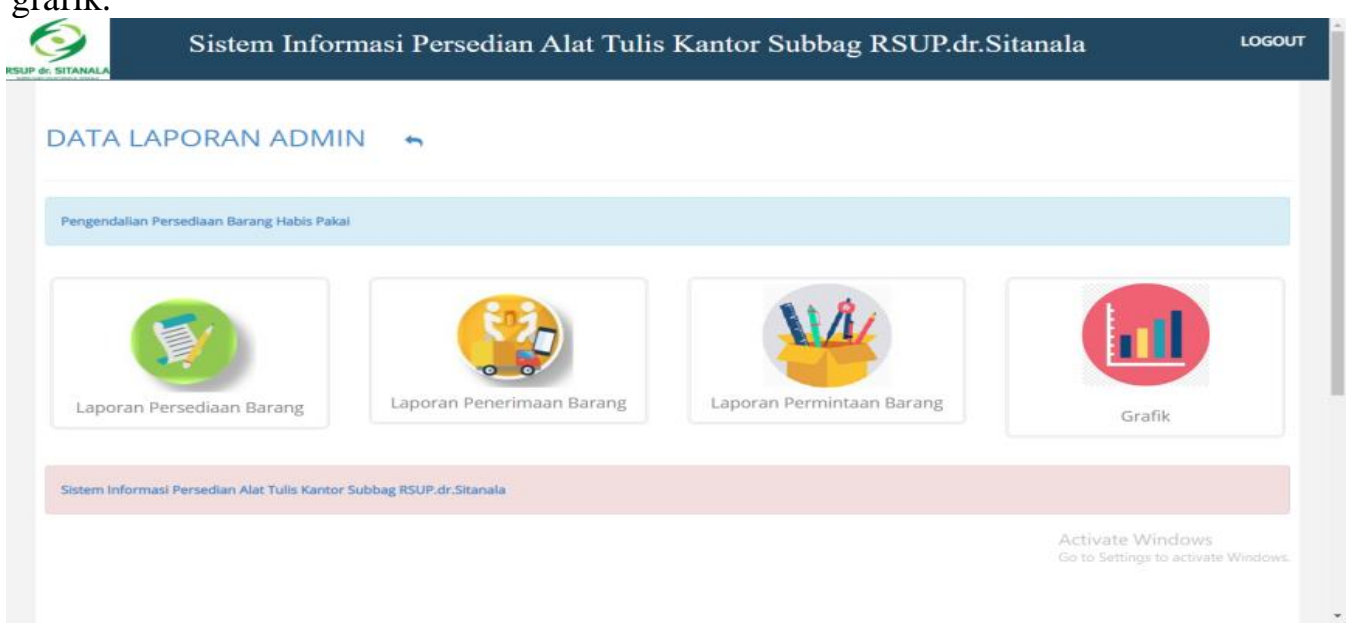

Gambar 8. Rancangan Tampilan Menu Laporan

\section{Kesimpulan}

Dari hasil pembahasan yang dilakukan diatas maka dapat ditarik kesimpulan bahwa pada proses sistem persedian barang yang berjalan pada RSUP dr.Sintanala masih dikerjakan secara manual dengan menggunakan form kertas dalam permintaan barang dan laporan permintaana barang sehingga pekerjaan yang dilakukan tidak optimal yang menimbulkan proses pencarian data tidak efekktif dan efisien. Oleh karena itu untuk mengotimalkan dan mempermudah pekerjaan, update data dan pembuatan laporan sering terjadi sehingga laporan yang di sajikan tidak akurat dan membutuhkan waktu yang cukup lama. Masalah tersebut dapat diatasi dengan diterapkanya sistem yang terkomputerisasi sehingga sistem persediaan alat tulis kantor (ATK) pada bagian RSUP dr.Sintanala dapat berjalan dengan efektif,efisien dan keakuratan data dapat terjaga. 
4. Saran

Diharapkan RSUD dr.Sintanala dapat mengubah sistem yang masih manual kedalam sistem yang teleh terkomputerisasi agar bisa mempermudah proses pengolahan, penyajian data dan pengiriman informasi penting sehingga bisa diterima oleh pihak yang berkepentingan secara cepat.

\section{Daftar Pustaka}

[1] Peraturan Menteri Kesehatan Republik Indonesia No. 340/MENKES/PER/III/2010.

[2] Nurjannah, E. (2018). Rancang Bangun Sistem Informasi Permintaan Alat Tulis Kantor pada Universitas Islam Negeri Alauddin Makassar (Doctoral dissertation, Universitas Islam Negeri Alauddin Makassar).

[3] Heizer, J. dan Render, B.2015. Operasional Management. Edisi Sebelas. Salemba Empat, Jakarta.

[4] Maimunah. David Ericson Manalu. Dian Budi Kusuma. 2017. Tangerang Perancangan Prototype Visual pada Bagian Desain Sebagai Media Informasi dan Promosi pada PT.Sulindafin. Seminar Nasional Teknologi Informasi dan Multimedia 2017 ISSN: 23023805. Hidayat, Arif. 2015. "Aplikasi Manajemen Kegiatan Untuk Organisasi Non Profit Berbasis Website”. Jurnal MIKROTIK Vol. 5 No 2.

[5] Susilowati, Emy Budi, dan Bambang Eka Purnama. 2017. Analisis Dan Perancangan Sistem Informasi Pasien Rumah Sakit Umum Nirmala Suri Sukoharjo. Speed-Sentra Penelitian Engineering dan Edukasi. Vol. 3 No. 4, ISSN: 1979-9330, 10-17.

[6] Warnars, H. L. H. S. (2015). Perbandingan penggunaan Database OLTP (Online Transactional Processing) dan Data Warehouse. Creative Communication and Innovative Technology (CCIT) journal, 8(1), 83-100

[7] Ariawan, Jesa dan Sri Wahyuni. 2015. Aplikasi Pengajuan Lembur Karyawan Berbasis Web. Jurnal Sisfo Tek Global. Vol.5 No.1-Maret 2015. ISSN : 2088 - 1762

[8] Saryani, S., Harfizar, H., \& Ardiansyah, A. (2019). Sistem Informasi Inventory Pemasukan dan Pengeluaran Data Barang ATK Pada Kelurahan Karangsari. Technomedia Journal, 4(1), 44-55.

[9] Sari, A. O., \& Nuari, E. (2017). Rancang Bangun Sistem Informasi Persediaan Barang Berbasis Web Dengan Metode Fast (Framework For The Applications). Jurnal PILAR Nusa Mandiri, 13(2), 261-266.

[10] Rahayu, S., Nurhaeni, T., \& Rohmah, M. (2015). Sistem persediaan alat tulis kantor sebagai penunjang pengambilan keputusan bagian logistik di perguruan tinggi raharja. Creative Communication and Innovative Technology Journal, 8(2), 91-101. 